\title{
POWER ENGINEERING: NUCLEAR POWER PLANTS AND RENEWABLE ENERGY SOURCES
}

\author{
Alexander Solovyev \\ Lomonosov Moscow State University, Russia \\ Andrey Pustovgar \\ Moscow State University of Civil Engineering, Russia \\ Aleksey Adamtsevich* \\ Moscow State University of Civil Engineering, Russia \\ Liubov Shilova \\ Moscow State University of Civil Engineering, Russia \\ Kirill Degtyarev \\ Lomonosov Moscow State University, Russia \\ Dmitry Solovyev \\ Joint Institute for High Temperatures of the Russian Academy of Sciences, Russia
}

The article considers a comparative dynamics of power engineering development based on the use of nuclear energy and renewable energy sources from 1960s up to now. The authors evaluate the parameters of environmental and economic efficiency, risks and prospects of power engineering development based on various types of energy carriers. It is shown that the reduction of the share of nuclear power engineering in the world energy balance cannot be compensated due to renewable energy sources, and it would cause the increase in the use of fossil fuels. The authors come to the conclusion about the necessity of a parallel development of both the renewable energy sources and the nuclear power engineering

Key words: Environment, Nuclear energy, Renewable energy sources, Power engineering politics

\section{INTRODUCTION}

The purpose of this study is revealing the role of nuclear power plants (NPP) as well as various types renewable energy sources (RES) in the process a non-carbon power engineering structure's formation. The study also gives a comparative evaluation of the aforesaid role, the attending increase in environmental and economic efficiency, contains the risk analysis concerned and the prospects of diversified power engineering's development. The article based on statistical and analytic materials, considers the dynamics of development of the world noncarbon power engineering within second half of the $X X$ century and early $X X I$, the comparative evaluation of trends and special features and the correlation of the nuclear power engineering development with the changes in the environment parameters as well as the environmental efficiency of various types of power engineering. The comparative evaluations of economic efficiency of power engineering are presented; the uncertainties and risks concerning NPP and RES and their influence on the prospects of noncarbon power engineering development are discussed.

\section{THE DYNAMICS OF DEVELOPMENT OF THE WORLD POWER ENGINEERING ON THE BASIS OF NUCLEAR AND RENEWABLE ENERGY SOURCES}

The share of nuclear energy in the world energy production has grown from $0.2 \%$ (6 MT, fuel equivalent) in 1965 to $4.4 \%$ (574 MT, fuel equivalent) in 2014 (Table 1, Fig. 1). There were two periods of nuclear power engineering development: the active growth (1965-1990s) and the stagnation (2000s - up to present). The maximum share $(6.1 \%$ to $6.3 \%)$ of nuclear energy in the world energy consumption structure was achieved in 1995 - 2002; since then this share is decreasing. The maximum value of nuclear energy consumption ran up to $635 \mathrm{MT}$ of fuel equivalent in 2006, later it became less, then stabilized and showed a slight growth in 2012-2014. 
Table 1: Dynamics and structure of world energy consumption in 1965-2014 with respect to the energy sources [01]

\begin{tabular}{|l|c|c|c|c|c|c|c|}
\hline Energy source & 1965 & 1975 & 1985 & 1995 & 2005 & 2014 \\
\hline Million ton, fuel equivalent & 1530 & 2692 & 2817 & 3291 & 3919 & 4211 \\
\hline Oil & 588 & 1064 & 1483 & 1925 & 2505 & 3066 \\
\hline Natural gas & 1395 & 1562 & 2077 & 2258 & 3122 & 3882 \\
\hline Coal & 3512 & 5318 & 6377 & 7474 & 9547 & 11158 \\
\hline Total fossil fuels & 6 & 82 & 335 & 526 & 626 & 574 \\
\hline Nuclear energy & 209 & 324 & 448 & 563 & 661 & 879 \\
\hline Hydro energy & 1 & 4 & 12 & 37 & 85 & 317 \\
\hline Other RES & 3728 & 5729 & 7173 & 8600 & 10920 & 12928 \\
\hline Total & $41,0 \%$ & $47,0 \%$ & $39,3 \%$ & $38,3 \%$ & $35,9 \%$ & $32,6 \%$ \\
\hline Share in the energy & consumption structure & & & $23,7 \%$ \\
\hline Oil & $15,8 \%$ & $18,6 \%$ & $20,7 \%$ & $22,4 \%$ & $22,9 \%$ & $30,0 \%$ \\
\hline Natural gas & $37,4 \%$ & $27,3 \%$ & $29,0 \%$ & $26,3 \%$ & $28,6 \%$ & $86,3 \%$ \\
\hline Coal & $94,2 \%$ & $92,8 \%$ & $88,9 \%$ & $86,9 \%$ & $87,4 \%$ & $4,4 \%$ \\
\hline Total fossil fuels & $0,2 \%$ & $1,4 \%$ & $4,7 \%$ & $6,1 \%$ & $5,7 \%$ & $6,8 \%$ \\
\hline Nuclear energy & $5,6 \%$ & $5,7 \%$ & $6,2 \%$ & $6,5 \%$ & $6,1 \%$ & $2,5 \%$ \\
\hline Hydro energy & $0,0 \%$ & $0,1 \%$ & $0,2 \%$ & $0,4 \%$ & $0,8 \%$ & $100,0 \%$ \\
\hline Other RES & $100,0 \%$ & $100,0 \%$ & $100,0 \%$ & $100,0 \%$ & $100,0 \%$ & \\
\hline Total &
\end{tabular}

Consumption of world primary energy with respect to the energy sources, MT, fuel equivalent, $1965-2014$

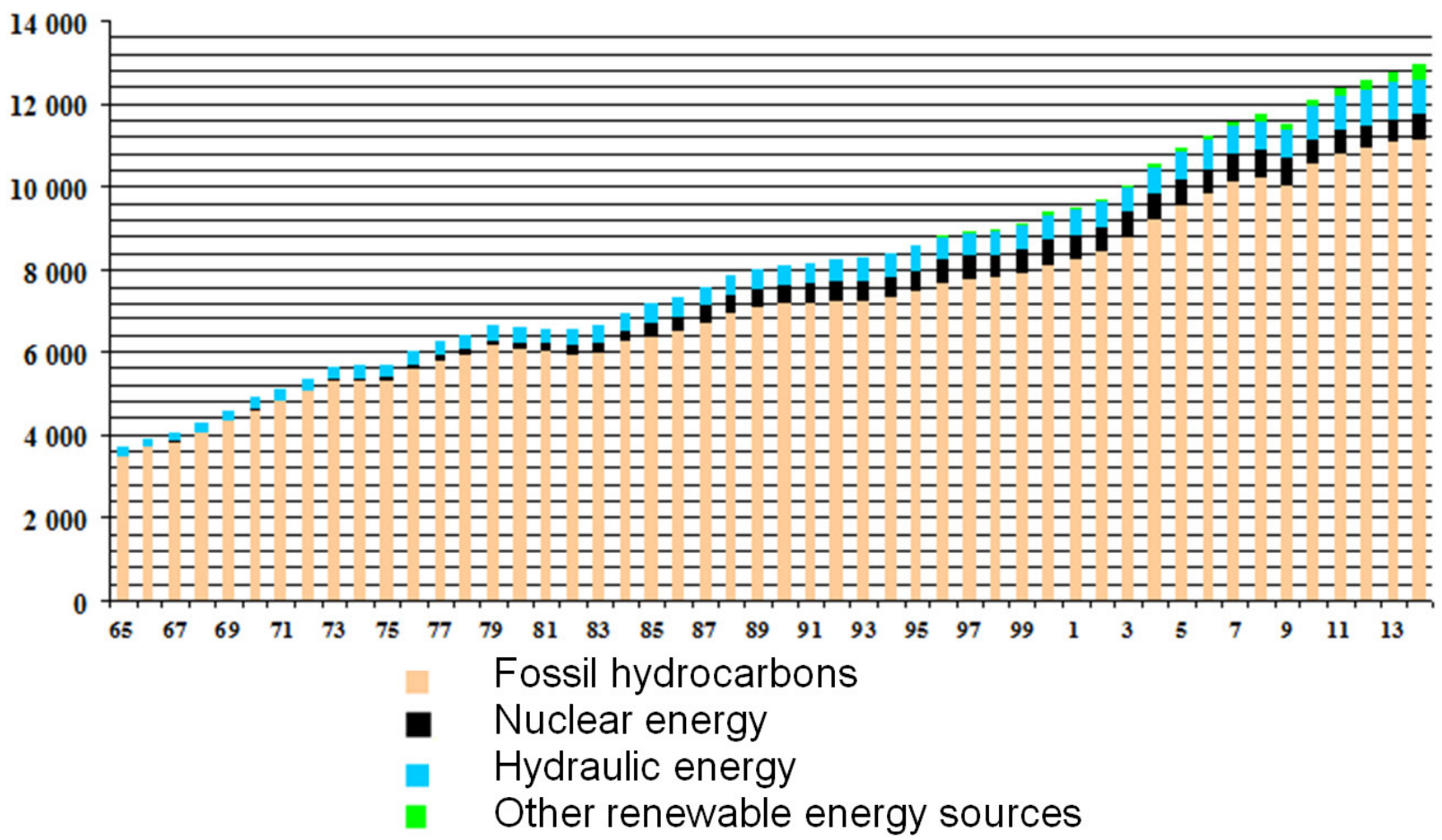

Figure 1: Dynamics and structure of consumption of the world primary energy, MT, fuel equivalent, 1965-2014 
Table 2: Dynamics and structure of electric energy production in 1980-2014, TWh, with respect to the production sources [02]

\begin{tabular}{|l|c|c|c|c|c|c|c|c|}
\hline Energy sources & 1980 & 1985 & 1990 & 1995 & 2000 & 2005 & 2010 & $\begin{array}{c}2014 \\
{[2]}\end{array}$ \\
\hline Electric energy production volume, TWh \\
\hline Fossil fuels & 5589 & 6041 & 7136 & 7787 & 9333 & 11437 & 13642 & 15715 \\
\hline Nuclear energy & 684 & 1426 & 1909 & 2210 & 2450 & 2625 & 2630 & 2537 \\
\hline Hydro energy & 1723 & 1952 & 2144 & 2453 & 2623 & 2905 & 3422 & 3885 \\
\hline \hline Other RES & 31 & 54 & 135 & 179 & 249 & 391 & 765 & 1401 \\
\hline \hline Total & 8018 & 9460 & 11304 & 12608 & 14627 & 17330 & 20437 & 23537 \\
\hline Share in the production structure, \% & & & & & \\
\hline Fossil fuels & $69,7 \%$ & $63,9 \%$ & $63,1 \%$ & $61,8 \%$ & $63,8 \%$ & $66,0 \%$ & $66,8 \%$ & $66,8 \%$ \\
\hline Nuclear energy & $8,5 \%$ & $15,1 \%$ & $16,9 \%$ & $17,5 \%$ & $16,7 \%$ & $15,1 \%$ & $12,9 \%$ & $10,8 \%$ \\
\hline Hydro energy & $21,5 \%$ & $20,6 \%$ & $19,0 \%$ & $19,5 \%$ & $17,9 \%$ & $16,8 \%$ & $16,7 \%$ & $16,5 \%$ \\
\hline Other RES & $0,4 \%$ & $0,6 \%$ & $1,2 \%$ & $1,4 \%$ & $1,7 \%$ & $2,3 \%$ & $3,7 \%$ & $6,0 \%$ \\
\hline Total & $100 \%$ & $100 \%$ & $100 \%$ & $100 \%$ & $100 \%$ & $100 \%$ & $100 \%$ & $100 \%$ \\
\hline
\end{tabular}

Shares of various energy carriers in the world production and consumption of electric energy in $1980-2014, \%$

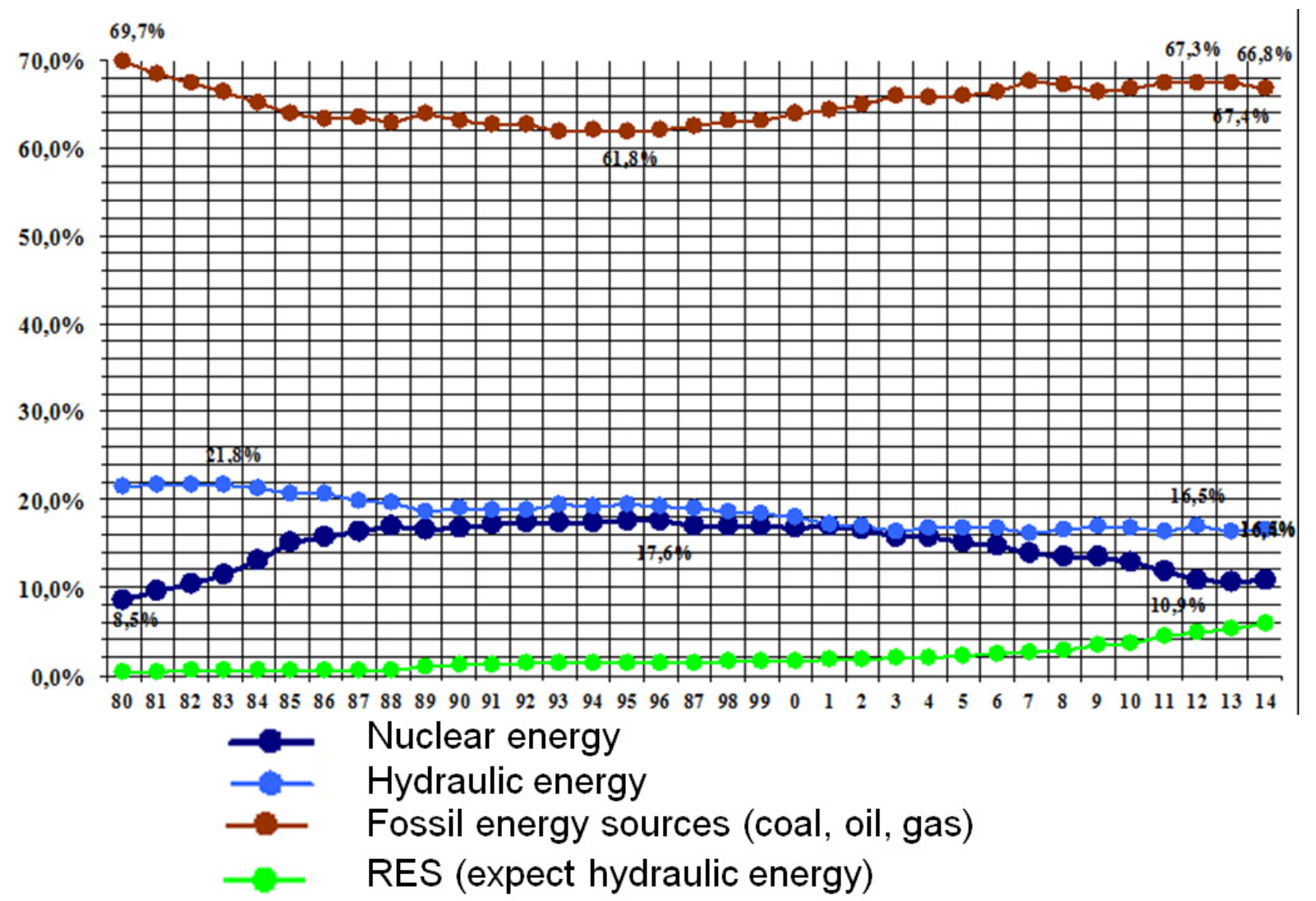

Figure 2: Shares of various energy sources in the world production and consumption of electric energy in 1980 - 2014 (1980-2012 [02], 2013-2014 [01]) 
This dynamic is more distinctly shown in the example of electric energy production (Table 2, Fig. 2 ), the share of which in the world energy production has grown from 31\% (9956 TWh, 2253 million ton, fuel equivalent) in 1985 to $41 \%$ (23537 TWh, 5326 million ton, fuel equivalent) in 2014.

The maximum share of nuclear power engineering in the world production of electric energy $(17.0 \%-17.6 \%)$ was achieved in $1993-1999$; later this share decreased $(11 \%$ in 2012$)$ and stabilized at the level of $10.7 \%-10.8 \%$ compared to other types of production. The maximum share of nuclear energy coincided with the minimum share of fossil fuels (Table 1). The reduction of the nuclear energy share caused a greater role of fossil energy carriers in the world energy balance. Their share in the world energy consumption grew up to $87.6 \%$ by 2007 and became less than $87 \%$ after 2012 . The share of fossil hydrocarbons in the world production of electric en- ergy returned to about $67 \%$ in the second half of 2000s. Partly, the reduction of the nuclear energy share was compensated due to the development of RES power engineering, but to a greater extent, it happened due to the growth of "fossil" power engineering (Table 3), first and foremost, in electric power engineering. Otherwise, the reduction of the share of "fossil" power engineering was mainly caused by the development of nuclear power engineering.

In the whole, the share of fossil hydrocarbons in the world consumption of primary energy decreased from $91.7 \%$ (1980) to $86.3 \%$ (2014), and the RES share (including hydro energy) increased from $5.9 \%$ to $9.3 \%$. At the same time, the electric energy production passed ahead of the total energy consumption volume, and this progress was due to either the nuclear power engineering (within the period of its active development) or the fossil hydrocarbons (during the its stagnation period).

Table 3: Dynamics of the shares of various energy carriers in the world energy balance in 1980-2014

\begin{tabular}{|c|c|c|c|c|c|c|c|c|}
\hline Energy source & 1980 & 1995 & 1980-1995 & 2010 & $1995-2010$ & 2014 & 2010-2014 & $1980-2014$ \\
\hline \multicolumn{9}{|c|}{ In the world consumption of primary energy } \\
\hline $\begin{array}{c}\text { Fossil } \\
\text { hydrocarbons } \\
\text { (coal, oil, gas) }\end{array}$ & $91,7 \%$ & $86,9 \%$ & $-4,8 \%$ & $87,0 \%$ & $+0,1 \%$ & $86,3 \%$ & $-0,7 \%$ & $-5,4 \%$ \\
\hline Nuclear energy & $2,4 \%$ & $6,1 \%$ & $+3,7 \%$ & $5,2 \%$ & $-0,9 \%$ & $4,4 \%$ & $-0,8 \%$ & $+2,2 \%$ \\
\hline Hydro energy & $5,8 \%$ & $6,5 \%$ & $+0,7 \%$ & $6,5 \%$ & $+0,0 \%$ & $6,8 \%$ & $+0,3 \%$ & $+1,0 \%$ \\
\hline Other RES & $0,1 \%$ & $0,4 \%$ & $+0,3 \%$ & $1,4 \%$ & $+1,0 \%$ & $2,5 \%$ & $+0,9 \%$ & $+2,4 \%$ \\
\hline Total RES & $5,9 \%$ & $6,9 \%$ & $+1,0 \%$ & $7,9 \%$ & $+1,0 \%$ & $9,3 \%$ & $+1,4 \%$ & $+3,4 \%$ \\
\hline \multicolumn{9}{|c|}{ In the world production of electric energy } \\
\hline $\begin{array}{c}\text { Fossil hydrocar- } \\
\text { bons (coal, oil, } \\
\text { gas) }\end{array}$ & $69,7 \%$ & $61,8 \%$ & $-7,9 \%$ & $66,8 \%$ & $+5,0 \%$ & $66,8 \%$ & $+0,0 \%$ & $-2,9 \%$ \\
\hline Nuclear energy & $8,5 \%$ & $17,5 \%$ & $+9,0 \%$ & $12,9 \%$ & $-4,6 \%$ & $10,8 \%$ & $-2,1 \%$ & $+2,3 \%$ \\
\hline Hydro energy & $21,5 \%$ & $19,5 \%$ & $-2,0 \%$ & $16,7 \%$ & $-2,8 \%$ & $16,5 \%$ & $-0,2 \%$ & $-5,0 \%$ \\
\hline Other RES & $0,4 \%$ & $1,4 \%$ & $+1,0 \%$ & $3,7 \%$ & $+2,3 \%$ & $6,0 \%$ & $+2,3 \%$ & $+5,6 \%$ \\
\hline Total RES & $21,9 \%$ & $20,9 \%$ & $-1,0 \%$ & $20,4 \%$ & $-0,5 \%$ & $22,5 \%$ & $+2,1 \%$ & $+0,6 \%$ \\
\hline
\end{tabular}

The time period from 1980 to 2014 was noted by the following processes: the RES share (including the hydraulic energy) in the world production of electric energy increased only by $0.6 \%$ (from $21.9 \%$ to $22.5 \%$ ); herewith the hydraulic energy share appreciably decreased (from $21.5 \%$ to $16.5 \%$ ), and the growth of the other
RES compensated the reduction of the hydraulic energy share meanwhile. It should be noted here that during the time period from 1973 to 2012 the RES share in the world energy production structure increased by $1.1 \%$ (from $12.4 \%$ to $13.5 \%$ ), and the nuclear energy share increased by $3.9 \%$ (from $0.9 \%$ to $4.8 \%$ ). 
Table 4: World energy production structure [03]

\begin{tabular}{|c|c|c|c|c|}
\hline \multirow{2}{*}{ Energy carrier } & \multicolumn{2}{|c|}{1973} & \multicolumn{2}{c|}{2012} \\
\cline { 2 - 5 } & $\begin{array}{c}\text { Energy produc- } \\
\text { tion, million ton, oil } \\
\text { equivalent }\end{array}$ & $\begin{array}{c}\text { World production } \\
\text { share }\end{array}$ & $\begin{array}{c}\text { Energy production, } \\
\text { million ton, oil } \\
\text { equivalent }\end{array}$ & $\begin{array}{c}\text { World production } \\
\text { share }\end{array}$ \\
\hline Coal & 1502 & $24,6 \%$ & 3878 & $29,0 \%$ \\
\hline Oil & 2815 & $46,1 \%$ & 4198 & $31,4 \%$ \\
\hline Gas & 977 & $16,0 \%$ & 2848 & $21,3 \%$ \\
\hline $\begin{array}{c}\text { Total fossil hy- } \\
\text { drocarbons }\end{array}$ & 5294 & $86,7 \%$ & 10924 & $81,7 \%$ \\
\hline Nuclear energy & $\mathbf{5 5}$ & $\mathbf{0 , 9 \%}$ & $\mathbf{6 4 2}$ & $\mathbf{4 , 8 \%}$ \\
\hline Hydro energy & 110 & $1,8 \%$ & 321 & $2,4 \%$ \\
\hline $\begin{array}{c}\text { Biofuel and } \\
\text { waste }\end{array}$ & 641 & $10,5 \%$ & 1337 & $10,0 \%$ \\
\hline OtherRES & 6 & $0,1 \%$ & 147 & $1,1 \%$ \\
\hline \hline TotalRES & $\mathbf{7 5 7}$ & $\mathbf{1 2 , 4 \%}$ & $\mathbf{1 8 0 5}$ & $\mathbf{1 3 , 5 \%}$ \\
\hline Total & 6106 & $100,0 \%$ & 13371 & $100,0 \%$ \\
\hline
\end{tabular}

Thus, the factual dynamics of development of the RES power engineering does not conform to common ideals about its rapid growth, and it is the nuclear energy which has the key role in the reduction of the fossil fuel share.

\section{Environmental efficiency of various power engineering types}

The dynamics of nuclear power engineering development correlates with the changes in environment parameters. In particular, a period of active growth of nuclear power engineering corresponds to a lesser $\mathrm{CO}_{2}$ emission into the atmosphere (Fig.3).

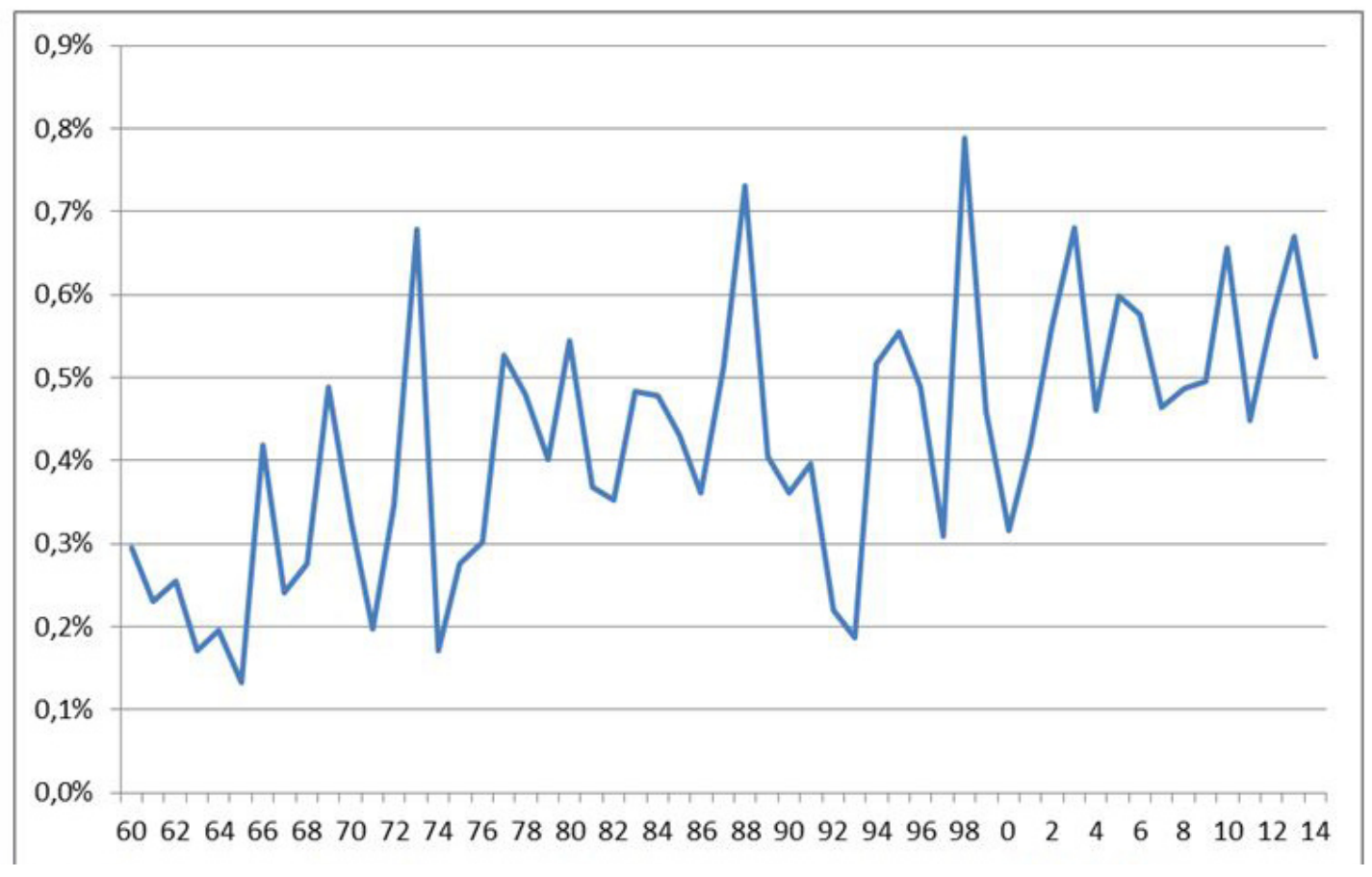

Figure 3: Dynamics of the $\mathrm{CO}_{2}$ emission into the atmosphere in 1960-2014 [04] 
Moreover among the most development countries, France has a lower value of the $\mathrm{CO} 2$ emission (Table 5); the nuclear energy share in the electric energy production in France is very high: more than $70 \%$. Herewith the RES share (including hydro energy) in France is about 16\%, which is lower than in other development countries (in Germany, the RES share is about $25 \%$ ).

Table 5: Per capita $\mathrm{CO}_{2}$ emissions (ton/person*year) in the most developed industrial countries in 2013 [05]

\begin{tabular}{|l|c|}
\hline Country & CO2, emission (ton/person*year) (2013) \\
\hline Australia & 16,9 \\
\hline USA & 16,6 \\
\hline Canada & 15,7 \\
\hline South Korea & 12,7 \\
\hline Russia & 12,6 \\
\hline Japan & 10,7 \\
\hline China & 7,4 \\
\hline EU as the whole & 7,3 \\
\hline Germany & 10,2 \\
\hline Great Britain & 7,5 \\
\hline Italy & 6,4 \\
\hline France & $\mathbf{5 , 7}$ \\
\hline
\end{tabular}

In general, the analysis of the whole life cycle of the energy production (from the production of energy carrier and the equipment concerned to the utilization of waste products and power plants themselves) gives the following average emission values [06] for various current energy production types in $\mathrm{CO}_{2}$ gram-equivalent for $1 \mathrm{kWh}$ of the electric energy produced.

- Heat (coal and gas) power plants - 490820;

- Bio-mass heat power plants - 230-740;

- Solar battery stations - 41-48;

- Geo-thermal stations - 38;

- Solar concentrators - 27;

- Hydro power plants - 24;

- Nuclear power plants - 12;

- Wind generator power plants - 11-12.

The external expenses for the production of 1 $\mathrm{kWh}$ may be considered as an integral parameter of environmental and economic efficiency. For the EU-countries, the values of this parameter (in Euro-cent $/ \mathrm{kWh}$ ) in 2003 were the following (according to [07]):

- Coal - 2-15;

- Oil-3-11;

- Gas-1-4;

- Solar battery energy - 0.6;
- Bio-mass energy - 0,1-5;

- Hydro energy - 0,1-1;

- Nuclear energy - 0.2-0.7;

- Wind energy - 0,1-0.25.

Thus, the NPP are quite competitive in comprison with the RES power plants; moreover, they are more efficient than all the others (but the wind power plants) with respect to environmental and economic parameters.

As to the economic efficiency of power engineering, the levelized energy costs of $1 \mathrm{kWh}$ are used as an integral parameter. The levelized energy costs include the investment component of expenses, the operational and the organizational ones. The total expenses including the expenses for the construction of power plants, the maintenance services, the organization and transaction expenses are distributed for the whole life-cycle of the power plant.

The calculation of levelized costs considers the following items: the investments for $1 \mathrm{~kW}$, the coefficient of use of rated power (CURP) of the power plant and the energy production value $(\mathrm{kW})$, the energy carrier costs, the financial coefficients connected with the money costs and the discount rate, the capital costs, etc. In particular, the [08] gives the calculated data concerning the levelized costs for the production of electric energy by various power plants types being 
introduced by 2020 (Table 6) with the following assumptions: time period -30 years, average capital cost $-6.5 \%$, CURP - see Table 6 . With the aforesaid assumptions, the total levelized costs of electric energy production are the following: 72-145 \$/MWh (7-15 cent/kWh) for heat power plants, 95 \$/MWh for nuclear power plants and 48-240 \$/MWh for renewable energy sources.

Table 6: Calculated levelized costs for the production of electric energy (\$MWh, 2013) for various power plant types being introduced in the USA by 2020

\begin{tabular}{|c|c|c|c|c|c|c|}
\hline Power plant type & $\begin{array}{c}\text { CURP, } \\
\%\end{array}$ & $\begin{array}{c}\text { Levelized } \\
\text { invest- } \\
\text { ments }\end{array}$ & $\begin{array}{c}\text { Permanent } \\
\text { operative } \\
\text { expenses }\end{array}$ & $\begin{array}{c}\text { Variable } \\
\text { operative } \\
\text { expenses } \\
\text { including } \\
\text { fuel) }\end{array}$ & $\begin{array}{c}\text { Transac- } \\
\text { tion ex- } \\
\text { penses }\end{array}$ & $\begin{array}{c}\text { Total } \\
\text { levelized } \\
\text { costs }\end{array}$ \\
\hline $\begin{array}{c}\text { Heat power plants } \\
\text { (coal and gas) }\end{array}$ & $30-85$ & $14,4-97,3$ & $1,7-9,8$ & $30,7-94,6$ & $1,2-3,5$ & $72,6-144,4$ \\
\hline Nuclear power plants & 90 & 70,1 & 11,8 & 12,2 & 1,1 & 95,2 \\
\hline $\begin{array}{c}\text { Geothermal power } \\
\text { plants }\end{array}$ & 92 & 34,1 & 12,3 & 0,0 & 1,4 & 47,8 \\
\hline Bio-mass power plants & 83 & 47,1 & 14,5 & 37,6 & 1,2 & 100,5 \\
\hline $\begin{array}{c}\text { Wind power plants } \\
\text { (at land and off shore) }\end{array}$ & $36-38$ & $57,7-168,6$ & $12,8-22,5$ & 0,0 & $3,1-5,8$ & $73,6-196,9$ \\
\hline $\begin{array}{c}\text { Solar power plants } \\
\text { (solar battery plants } \\
\text { and solar heat plants) }\end{array}$ & $20-25$ & $109,8-$ & $11,4-42,1$ & 0,0 & $4,1-6,0$ & $125,3-239,7$ \\
\hline Hydro power plants & 54 & 70,7 & 3,9 & 7,0 & 2,0 & 83,5 \\
\hline
\end{tabular}

Thus, the electric energy produced at NPP is quite competitive as well. The RES power plants also approach the price competitiveness level. In recent years there is counter movement - while reducing investment costs to RES is their growth capacity on fossil fuel. The latter fact is connected with the requirements to the productivity of power plants and to their environmental characteristics; in particular, the installation of carbon capture and storage equipment at HPP causes a considerable growth of investment expenses for $1 \mathrm{MW}$ (Table 7). The technological and environmental improvement of gas and coal heat power plants causes the increase of investment and permanent operative expenses by 2 to 3 times. The additional safety measures in the process of construction of nuclear power plants also make the investment expenses higher.

Table 7: Calculated average investment expenses (\$/kW) for various power plant types in 2013 [09]

\begin{tabular}{|c|c|}
\hline Heat power plants (coal and gas) & $917-7.108$ \\
\hline Nuclear power plants & 5.530 \\
\hline Bio-mass power plants & $4.114-8.188$ \\
\hline Wind power plants (at land) & 2.213 \\
\hline Off shore wind power plants & 6.230 \\
\hline Solar (heat and PV) power plants & $4.183-5.067$ \\
\hline Hydro power plants & 2.936 \\
\hline
\end{tabular}

The assumptions on the CURP for wind and solar power plants (US EIA) are rather optimistic, significantly differing in the direction of increase of the actual CURP at the plants. At the same time, we should note the key role of the CURP for the economic and environmental efficiency of power plants. In particular, the CURP for the land wind power plants equals $36 \%$ (Table 6 ) as compared with the CURP for nuclear power plants equal to $90 \%$ means that the wind power neces 
On the basis of the aforesaid data on production capacities and production volumes by years, the authors calculated the world average CURP value for the time period from 1997 to 2014. For this calculation, the production output was compared with the average capacity values for both the previous year and the given one with consideration of introduction of new power plants. For instance, for the calculation of the average CURP value of solar world power plants in 1997, we took the arithmetic mean for the capacity values in 1996 (386 MW) and in 1997 (502 MW) equal to $444 \mathrm{MW}$. Further, we divided the electric energy production output at world solar power plants in 1997 (equal to 732 GWh by $444 \mathrm{MW}$ and obtain the production output of $1.649 \mathrm{~W}$ for $1 \mathrm{~W}$ of the capacity value. The maximum annual output equals the value of 8.760 ( 1 year=8.760 hours) and corresponds to the CURP value equal to $100 \%$. The factual CURP is calculated through the division of factual electric energy production value by the maximum possible value, and here it equals 1.649/8.760 $=18,8 \%$ (the average CURP value for solar power plants in 1997). In this way, the CURP values were calculated for solar and wind power plants in 1997 -2014 (Fig.5).

Dynamics of average CURP values (\%) for solar and wind world power plants in 1997 - 2014

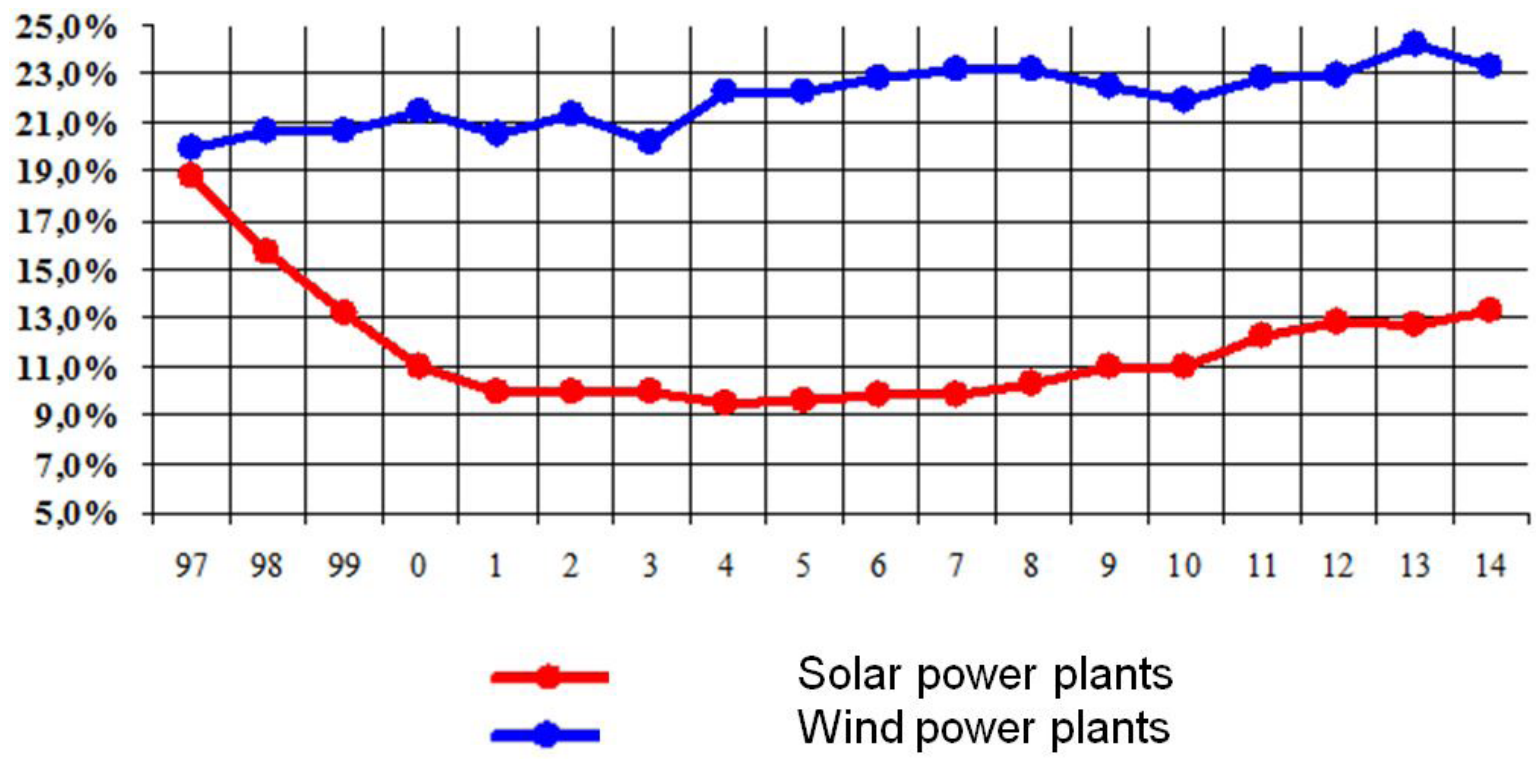

Figure 5: Dynamics of average CURP values for solar and wind world power plants in 1997-2014 (on the basis of the data from BP Statistical Review of World Energy, 2015).

Table 8: Principal parameters of development of solar and wind world power engineering in 1996-2014

\begin{tabular}{|c|c|c|c|c|c|}
\hline \multicolumn{2}{|c|}{ Parameters } & $1996-2000$ & $2001-2005$ & $2006-2010$ & $2011-2014$ \\
\hline \multicolumn{3}{|c|}{ Solar power engineering } \\
\hline $\begin{array}{c}\text { The capacities introduced by the } \\
\text { end of the time period, MW }\end{array}$ & 1275 & 5083 & 41345 & 180396 \\
\hline $\begin{array}{c}\text { Average annual capacity increase } \\
\text { rates for the time period }\end{array}$ & $35,0 \%$ & $32,0 \%$ & $52,9 \%$ & $45,4 \%$ \\
\hline $\begin{array}{c}\text { Annual output for the last year of } \\
\text { the time period, GWh }\end{array}$ & 1029 & 1029 & 31411 & 185882 \\
\hline $\begin{array}{c}\text { Average annual production output } \\
\text { increase rates for the time period }\end{array}$ & $10,4 \%$ & $29,2 \%$ & $54,3 \%$ & $57,5 \%$ \\
\hline $\begin{array}{c}\text { Average CURP value for the time } \\
\text { period }\end{array}$ & $14,7 \%$ & $9,8 \%$ & $10,4 \%$ & $12,8 \%$ \\
\hline
\end{tabular}




\begin{tabular}{|c|c|c|c|c|}
\hline \multicolumn{5}{|c|}{ Wind power engineering } \\
\hline $\begin{array}{c}\text { The capacities introduced by the } \\
\text { end of the time period, MW }\end{array}$ & 17934 & 59186 & 197736 & 372961 \\
\hline $\begin{array}{c}\text { Average annual capacity increase } \\
\text { rates for the time period }\end{array}$ & $30,3 \%$ & $27,1 \%$ & $27,3 \%$ & $17,2 \%$ \\
\hline $\begin{array}{c}\text { Annual output for the last year of } \\
\text { the time period, GWh }\end{array}$ & 29481 & 104306 & 343364 & 706175 \\
\hline $\begin{array}{c}\text { Average annual production output } \\
\text { increase rates for the time period }\end{array}$ & $29,3 \%$ & $29,0 \%$ & $26,1 \%$ & $19,9 \%$ \\
\hline $\begin{array}{c}\text { Average CURP value for the time } \\
\text { period }\end{array}$ & $20,4 \%$ & $21,3 \%$ & $22,6 \%$ & $23,3 \%$ \\
\hline
\end{tabular}

The calculation shows that by the end of the considered time period the CURP of solar power plants decreased from $19 \%$ to $13 \%$ with the minimum CURP value of $9,5 \%$ in 2004then a gradual increase emerged, although the maximum values of the late 90 s have not been achieved. The CURP of wind power plants slightly increased from $20 \%$ at the end of 1990 s to $23 \%-25 \%$ in recent years.

The calculated CURP values (US Energy Information Administration, Table 6) for solar and wind power plants under construction are, respectively, $20 \%-25 \%$ and $36 \%-38 \%$; these values seem to be set too high.

Thus, there is no reason for considering the curtailment of nuclear power engineering to be compensated by the development of the RES power engineering. More probably, this process will cause the growth of the use of fossil hydrocarbon energy carriers. The opposition of nuclear and renewable power engineering seems to be counter-productive. A more constructive approach is a parallel development of nuclear and renewable power engineering and their mutual complementation.

At present, the current situation shows that for the majority of the countries, electricity generation at nuclear power plants is not more expensive than at pulverized coal thermal power plants and especially gas-oil thermal power plants [03].

Within the next 50 years the mankind will consume energy more, than it was consumed in the whole previous history [12]. Earlier forecasts about the growth of energy consumption and the development of new energy technologies haven't come true: the level of consumption is growing much faster, and renewable sources of "green" do not always allow you to get the required amount of energy at competitive prices.
The issue of shortage of fossil energy resources is getting ever more acute. The possibilities of building new hydroelectric power stations are also very limited. Do not forget about the fight against the "greenhouse effect", which imposes restrictions on the burning of oil, gas and coal in thermal power plants (TPP) [05].

The solution to the problem can be the active development of nuclear power, one of the youngest and dynamically developing sectors of the global economy. An increasing number of countries today come to the need to begin to develop a peaceful atom.

It is obvious that the cost of "nuclear" electricity can be very high if it includes a fund for insurance of risks of accidents and health of the population living near NPP, handling of radioactive waste, etc. Expenses which the system of insurance isn't able to cover subsequently become the expenditures of budgets of the affected states, which can be considered as a hidden subsidy of the nuclear industry. Thus, the owners of nuclear facilities do not fully pay their risks and transfer them to society as a whole.

The nuclear power engineering has its own problems: uneconomical use of nuclear fuel in water-moderated reactors [12], ensuring safe operation of NPP equipment and storage of waste nuclear fuel. However, these problems have some technological solutions, in particular, fast reactors and other developments, related to the minimization of the risk of accidents during the operation of power equipment, the creation of a closed-cycle nuclear power engineering using ${ }_{92}^{238} \mathrm{U}$ and ${ }_{90}^{232} \mathrm{Th}$.

In addition to that, the developments in the field of controlled thermonuclear fusion seem to be quite real, and the success in the field will result in the introduction of a powerful ecological 
energy source which is practically inexhaustible. There are also some particular developments improving the work of nuclear power plants: resource saving systems, improvement of environmental safety of heat-and-mass transfer hydro systems [13].

\section{CONCLUSIONS AND POLICY IMPLICATIONS}

The analysis of development of nuclear power engineering and renewable one since 1960s shows the key role of nuclear power engineering in the process of formation of a non-carbon trend in power engineering and reduction of negative effects on the environment.

The reduction of the share of fossil hydrocarbon fuels in the process of electric energy production since 1960 s as well as a certain reduction of the $\mathrm{CO} 2$ emission rates clearly correlates with the development of nuclear power engineering; the share of other non-carbon energy carriers mostly reduced due to the decrease in the share of hydraulic power engineering. The share of nuclear energy in the world energy balance has reduced since 1990s, and the electric energy production output at nuclear power plants has reduced since 2000s. It was not compensated by the growth of the renewable energy production, and, on the contrary, it caused an increase in the share of fossil hydrocarbons in the world electric energy production. It also correlates with a new increase in the $\mathrm{CO} 2$ emission into the atmosphere.

For all that, there has been a steady decrease in the development of renewable power engineering since 2010s. The increase rates for the electric energy production output at wind and solar power plants are less than the increase rates for the production capacities. This fact points out certain barriers in the development of renewable power engineering, which may be worse in the near future.

A comparative estimate of economic and environmental parameters of nuclear power plants and RES power plants points out a high competitiveness of NPP with respect to the both aforesaid parameters.

The trends in the field and the analysis of environmental and economic parameters show that the nuclear power engineering is a necessary component in the process of transition to a noncarbon power engineering and reduction of envi- ronmental risks. A nihilistic attitude to the nuclear power engineering and its opposition to renewable energy sources seem to be unfounded. The analysis of development of world power engineering for the period of 50 to 55 last years as well as the consideration of current trends in the field point out the expediency of development of both renewable and nuclear power engineering, which are mutually complementary.

\section{REFERENCES}

1) BP, "BP Statistical Review of World Energy June 2015," Br. Pet., no. June, p. 48, 2015.

2) EIA, "Today in Energy - Daily Prices - Prices - U.S. Energy Information Administration (EIA)," US Energy Information Administration, 2017. .

3) IEA, "Key World Energy Statistics 2014," 2014.

4) "Mauna Loa Observatory (MLO): Daily CO2," https://www.co2.earth, 2017. [Online]. Available: https://www.co2.earth/daily-co2? [Accessed: 14-Sep-2017].

5) J. G. Olivier, G. Janssens-Maenhout, M. Muntean, and J. A. H. . Peters, Trends in global CO2 emissions: 2014 Report, vol. 1490. 2014.

6) S. Schlomer, T. Bruckner, L. Fulton, E. Hertwich, A. McKinnon, D. Perczyk, J. Roy, R. Schaeffer, R. Sims, P. Smith, and R. Wiser, "Annex III: Technology-specific cost and performance parameters," Clim. Chang. 2014 Mitig. Clim. Chang. Contrib. Work. Gr. III to Fifth Assess. Rep. Intergov. Panel Clim. Chang., pp. 1329-1356, 2014.

7) EC, "External costs: Research results on socio-environmental damages due to electricity and transport," 1997.

8) Energy Information Administration, "Levelized Cost and Levelized Avoided Cost of New Generation Resources in the Annual Energy Outlook 2016," US Energy Inf. Adm., no. August, pp. 1-20, 2016.

9) U. S. E. I. Adminstration, "Updated Capital Cost Estimates for Utility Scale Electricity Generating Plants," US Dep. Energy, no. April, pp. 1-201, 2013. 
10) A. Soloviev, K. Degtyarev, A. Zalikhanov, and K. Chekarev, "Regional and local geographical potentials of renewable energy sources in Russia - доклад на конференции," International Geographical Union (IGU) Regional Conference 2015, 2015. [Online]. Available: http://demo.istina.msu.ru/conferences/presentations/10622309/. [Accessed: 14-Sep2017].

11) O. Andersen, Unintended Consequences of Renewable Energy, vol. 140. 2013.

12) V. V Kostyuk, A. A. Makarov, and T. A. Mitrova, "Energy and geopolitics," portal RFBR.[Electronic Resour. http//www rfbr. ru" RFBR" Bull., 2011.

13) K. Degtyarev, A. Zalikhanov, Beryozkin M., A. Solovyev, and O. Sinyugin, "Innovations in renewable energy - the start-ups of scientific cooperation - доклад на конференции," in Swiss energy seminar Watt d'Or, 2015.

Paper sent to revision: 18.07.2017.

Paper ready for publication: 14.09.2017. 